\title{
REFLECTIONS
}

\section{Mourning My Patient, Mr Schwartz}

Rutb Kannai, MD

Aya Rice Alon, $\mathrm{MA}^{2}$

'Department of Family Medicine, BenGurion University of the Negev, Beersheba, Israel

${ }^{2}$ Department of Counseling and Human Development, Haifa University, Mount Carmel, Haifa, Israel
Conflict of interest: authors report none.

\section{CORRESPONDING AUTHOR}

Dr Ruth Kannai

6B Apt. 2 Reuven Street

Bet Shemesh Israel 99544

rkannai@gmail.com

\begin{abstract}
The story depicts my close relationship with Mr Schwartz, an elderly Holocaust survivor, spanning over 20 years. During those years, he became a significant patient to me; during my many home visits, we often shared significant conversations about life. When Mr Schwartz was diagnosed at age 90 with advanced cancer, we made an alliance whereby I would represent him in his decision not to receive medical interventions. For the next 4 years until his death, Mr Schwartz pleaded with me to kill him, which I could not do either legally or morally.

Over the years; I was moved by his honesty, frustrated at my inability to offer him relief or a sense of meaning, and pensive, as I would inevitably reflect on existential issues pertaining to myself and my dear ones. Mourning his loss was complex, for I was very close to him, yet not a part of his family. With whom can we physicians share our sadness at the loss of a person with whom we never actually spent a holiday or family dinner?
\end{abstract}

Ann Fam Med 2021;19:460-462. https://doi.org/10.1370/afm.2710.

$\mathrm{F}$ or 20 years, before every holiday, I would receive a phone call from my longtime patient Mr Schwartz, exclaiming in a heavy Hungarian accent, "Happy holiday, Dr Kannai!" Years before his death, I had given $\mathrm{Mr}$ Schwartz my personal phone number so he could call me in the evenings if his respiratory symptoms did not improve. Medical hospitalization was indicated due to his deteriorating COPD; however, I allowed him to remain at home, on the condition he comply with the antibiotics, inhalers, and oxygen and call me with updates.

Mr Schwartz was 70 when his wife Vera died, after which I began the visits to his small home. Mr Schwartz, like my own father, was a Holocaust survivor. Thus, I thought he had no extended family. Only much later did I discover he had a son, who was married with children. $\mathrm{Mr}$ Schwartz was completely independent in his medical care and he never spoke of his son and family, so I had the sense that he was utterly alone in the world.

With every visit, Mr Schwartz would welcome me on his porch overlooking the road, an ubiquitous box of cigarettes by his side, alternating between his oxygen and his cigarette in a mischievous manner that would awaken the responsible adult within me to say, "Quit smoking, it's dangerous for your health!" This would only encourage him to break into a smile revealing his missing teeth, as he produced the usual gift for both me and the accompanying nurse: a package of Mentos gum for each, which we would gracefully accept. It was our ritual. The Mentos package would remain in my glove compartment for the coming weeks, untouched, until I would eventually dispose of it, only to be replaced by the next delivery.

After completing our regular ritual, each of us adhering to the expected protocol, Mr Schwartz would extinguish his cigarette out of courtesy, and we would then speak at ease. Mr Schwartz was completely lucid, sharp as a razor, and with a cynical sense of humor. His humor was for me a sign of his excellent cognitive condition and a useful tool in coping with his depression and loneliness. For example, he would celebrate 
his birthday twice a year, for as he said, "Just in case, because who knows, at my age...." He would update us about the latest episodes of "Big Brother," a popular reality show. He never missed an episode. For years, he would go twice a week to the Day Center for the elderly in the adjacent village, where he would sit alongside the meticulously dressed Hungarian women (men were quite scarce in his cohort...) and play poker the entire morning. Mr Schwartz believed that, at his age, he should be allowed to do whatever he well pleased. I couldn't have agreed more.

Mr Schwartz was an atheist, in fact, God, for him, died in the Holocaust. To put it another way: God exists, but Mr Schwartz would make it a point to spite Him at every opportunity: to mix milk and meat, to eat leavened bread during Passover, and never to pray-not even by accident. I understood his attempts at heresy and sarcasm-I viewed it as his way of coping with the physical and emotional pains so common at his age.

For years I warned him about his smoking and its possible consequences, to which he would smile and innocently reply, "After the smoke I inhaled from the crematoriums, a few cigarettes (3 packs a day) won't affect me much." And he was right. His pancreatic cancer was accidentally discovered when hospitalized for a COPD exacerbation. In the far corner of the CT of his lungs, the tumor could be discerned. When the scan was broadened to include the abdomen-a typical picture of pancreatic cancer could be seen with liver metastases. Mr Schwartz felt fine. He immediately understood the situation and announced there was no problem, he had lived enough years, and nearly 20 years beyond the death of his beloved wife. The oncologists suggested a biopsy to confirm the diagnosis, but Mr Schwartz was uninterested in any treatment. I agreed with him, but asked him to meet an oncologist I trusted, to summarize the findings, to hear about the recommended treatments, and to have information regarding the expected development of the illness, so that he could make a decision based on facts and not based on his fear regarding the treatment and its effects.

However, Mr Schwartz announced that he was officially done with tests, treatments, and hospitals, and hoped death would come for him quickly and easily. He also asked to not be resuscitated or to have any artificial life support. He didn't want to fill out any forms or testify before his family. "I know and you know-and that's enough." He was 90, and his decision was understandable. If a patient chooses to allow their illness to develop its natural course, I support their request to not intervene in ways that may prolong their suffering. Therefore, I wholeheartedly accepted Mr Schwartz's
DNR — do not resuscitate—request. I placed a "sticky note" on his computerized medical file: "DNR—at the patient's request."

I hoped his death would be quick and painless, but the cancer was slow. Mr Schwartz lived for 4 years with his untreated pancreatic cancer, during which the cancer caused almost no pain. Mr Schwartz had hardly any symptoms, and if he hadn't shown a slow and steady loss of weight, I might have thought his imaging results were wrong.

As time passed, the topics of our conversations narrowed.

"What is bothering you, Mr Schwartz? What would you like?"

"To die. The time has come, don't you think?"

"You know I cannot help you with that. I can help you reduce the suffering and pain, to help you function in daily life. Beyond that, I can only offer you my true care and understanding."

"Kill me if you care about me, I have lived enough."

His words would spiral in my stomach, with their uncensored candidness and unapologetic demand, which I could not fulfil.

Mr Schwartz eventually suffered increasing losses: he gradually became bedridden and confined to a wheelchair. He was embarrassed to go to the Day Center with his caretaker, in a wheelchair, in diapers. The only thing that remained was his intelligence and lucidity. In his final years he also lost his sense of humor. When I would come for a home visit he would repeatedly ask if I could kill him. When he received my usual reply, he would abruptly answer: "You can't kill me? What reason do I have to live?" I admitted I could identify with his wish, but I explained that physician-assisted suicide is illegal in Israel; Mr Schwartz had little patience for philosophical conversations. He wanted to die and was angry at me and the nurse for not assisting him with this. We offered antidepressants, sleeping pills, painkillers-but his depression was existential.

I felt helpless that I could not alleviate his pain. However, even if physician-assisted suicide was legal in Israel, I would be morally unable to administer it, as I believe in the sanctity of life. At the same time, I also believe every individual deserves to die with respect. I felt the tragedy of the situation, of his inability to die, and understood his anger was not really directed towards me, but towards life itself. I could not take away his existential pain. As for my own sadness, I chose to process it in my usual way: through teaching an annual course on end-of-life ethics in the academia, through self-reflection, and through writing.

"Happy holiday, Dr Kannai." Another New Year and another Passover and many more packets of 
Mentos, and Mr Schwartz did not die. I found myself praying for him. To die. To be collected by his ancestors who died over 70 years ago. Mr Schwartz became not only my patient, but my close friend. We shared a secret: his desire to die. He did not share this with his son and daughter-in-law and I could not speak to them without his permission. There was a certain tension between his family and me, as they had different ideas about his end-of-life care. Once, for example, while his son was abroad, his daughter-in-law transferred him to an old-age home, from where I immediately discharged him, based on his own request.

"Happy holiday, Mr Schwartz." Another year and yet another year passed. I routinely blessed him at the end of each conversation: "May you feel well, may you have strength, happy new year!" "I don't want happy and I don't want a new year, Dr Kannai, I want to die." was his reply.

Finally, death gathered him. His condition deteriorated and his son took him to the emergency unit. He didn't consult with me and all I could do was call the doctors there and testify to what Mr Schwartz requested long ago: DNR. Allow him to die. This was his true desire.

I did not go to the funeral, but went to the shiva, a Jewish custom of mourning for 7 days after a family member dies. Immediately after the funeral, the deceased's family stops their life for a week to sit shiva for their beloved. Friends and family gather to recount the deceased's life story and to share condolences. I was in an uncomfortable position of being his closest confidante yet nearly a stranger to his real family.

What do we, as family doctors, do with our mourning over someone who is not a family member? With whom can we share our sadness at the loss of one with whom we never actually spent a holiday or a family dinner, yet over months and years we shared countless conversations: humorous, cynical, personal, amusing?
The grief of the medical staff has no place and very little legitimacy. Mr Schwartz was one of my special patients. A dear person who touched my life for many years. I was moved by his honesty, frustrated at my inability to offer him relief or a sense of meaning, and pensive, as I would inevitably reflect on existential issues pertaining to myself and my dear ones. I came to accept that even if I felt unable to help, the mere act of my showing up consistently for Mr Schwartz was in fact a gift I could give him, for at least he was not alone with his despair and anger. I suppose it is a question of personality, willingness, and an openness to contend with such difficult issues, as both a physician and as a human being. I was touched on both levels by Mr Schwartz.

I allowed him to enter my heart through every phone call. I allowed him to endow me with small invaluable gifts, which expressed his affection and attention. I allowed him to have an impact on my willingness to remain open to such personal connections, for this is the heart and soul of family medicine.

However, dozens of other sympathetic elderly patients are on my caseload and I must carry on. I have no one with whom to share the story of our unique friendship. The last packet of Mentos still remains in my glove compartment: I don't want to consume it and I can't yet throw it away. Another holiday passes and yet another, and I miss his familiar voice: "Happy holiday, Doctor." I continue the conversation in my head and share with Mr Schwartz: "Thank you for trusting me with your innermost feelings. Thank you for teaching me the value of emotional intimacy between doctors and patients. Goodbye, Mr Schwartz."

To read or post commentaries in response to this article, go to https://www.AnnFamMed.org/content/19/5/460/tab-e-letters..

Key words: physician narrative; doctor-patient relationship; advance care planning; palliative care

Submitted August 20, 2020; submitted, revised, March 3, 2021; accepted March 29, 2021. 